\title{
PEMBERIAN EKSTRAK ENZIM KASAR DARI CAIRAN RUMEN DOMBA PADA TEPUNG BUNGKIL KEDELAI LOKAL DAN PENGARUHNYA TERHADAP PERTUMBUHAN IKAN NILA
}

\author{
Titin Kurniasih"), Indira Fitriliyani"*), Irma Melati", dan Zafril Imran Azwar") \\ *) Balai Penelitian dan Pengembangan Budidaya Air Tawar \\ Jl. Raya Sempur No. 1, Bogor 16154 \\ E-mail: titink2008@yahoo.com \\ **) Fakultas Perikanan dan Ilmu Kelautan, Universitas Lambung Mangkurat \\ Jl. Jenderal A. Yani km. 36, PO Box 6, Banjarbaru 70714
}

(Naskah diterima: 18 April 2011; Disetujui publikasi: 19 April 2012)

\begin{abstract}
ABSTRAK
Kendala utama yang dihadapi dalam upaya pencarian bahan baku lokal sumber protein alternatif untuk mendapatkan pakan yang ekonomis dan efisien antara lain kualitas bahannya yang tidak sebaik tepung ikan dan tepung bungkil kedelai impor. Enzim protease, amylase, dan selulase bermanfaat untuk meningkatkan kecernaan bahan baku yang mengandung protein kompleks, karbohidrat, dan serat yang tinggi. Cairan rumen ternak domba telah dideteksi banyak mengandung enzim yang dapat membantu meningkatkan kecernaan bahan baku nabati. Penelitian ini bertujuan untuk memanfaatkan sumber enzim alamiah yang murah dan tersedia cukup banyak di Indonesia, yaitu cairan rumen domba, untuk menghidrolisis bahan baku tepung bungkil kedelai lokal (TBKL). Penelitian ini terdiri atas dua tahap yaitu in vitro dan in vivo. Penelitian in vitro bertujuan mengevaluasi kadar produk hidrolisis yang dihasilkan setelah TBKL diinkubasi dengan ekstrak enzim kasar dari cairan rumen domba (EEK CRD) dengan dosis $0,200,400,600$, dan $800 \mathrm{~mL} / \mathrm{kg}$ TBKL, dan hasilnya adalah bahwa kadar total gula dan protein terlarut pada TBKL terhidrolisis meningkat apabila konsentrasi EEK CRD bertambah. Penelitian in vivo bertujuan menguji pemakaian TBKL yang telah dihidrolisis dengan dosis yang terpilih (dosis $800 \mathrm{~mL}$ EEK CRD/kg TBKL) dalam formulasi pakan ikan nila dengan 5 perlakuan dan 3 ulangan. Ikan uji adalah nila berukuran rata-rata 2,48 $\pm 0,0183 \mathrm{~g}$ per ekor, dan dipelihara di 15 akuarium berukuran $50 \mathrm{~cm} \times 60 \mathrm{~cm} \times 50 \mathrm{~cm}$ yang diisi masing-masing 10 ekor selama 40 hari percobaan. Hasil penelitian menunjukkan bahwa penggunaan TBKL terhidrolisis dalam formulasi pakan menghasilkan peningkatan signifikan $(P<0,05)$ pada parameter efisiensi pakan dibandingkan pakan kontrolnya, tetapi tidak signifikan $(P>0,05)$ untuk parameter laju pertumbuhan, konsumsi pakan, retensi protein, dan retensi lemak. Tidak ada perbedaan signifikan $(P>0,05)$ untuk tingkat sintasan di antara kelima perlakuan. EEK CRD dapat meningkatkan efisiensi pemanfaatan pakan melalui predigestion terhadap nutrien protein kompleks dan karbohidrat dalam suatu bahan.
\end{abstract}

KATA KUNCl: enzim, cairan rumen domba, tepung bungkil kedelai, pertumbuhan, nila 
ABSTRACT: The addition of extracted crude enzyme of sheep rumen liquor to local soybean meal and it's effects on growth performance of nile tilapia. By: Titin Kurniasih, Indira Fitriliyani, Irma Melati, and Zafril Imran Azwar

\begin{abstract}
The main constraint facing the efforts in utilizing locally alternative feed ingredients as protein sources in order to find out an economically efficient feed formulae is the less quality of the alternatives compared to imported fish meal and soybean meal. Protease, amylase and cellulase were beneficial in improving digestibility of ingredients with high content of complex protein, carbohydrate and fibre. Rumen liquor of sheep was detected to contain many types of enzymes which enable to improve the digestibility of plant protein ingredients. The objective of this research was to utilize a widely available source of natural digestive enzymes of rumen liquor, to hydrolyze local soybean meal. This research consisted of two steps, in vitro and in vivo experiments. The in vitro experiment determined to evaluate and measure the degraded products obtained from the incubation of soybean meal using extracted ruminal enzymes with doses of $0,200,400,600$, and $800 \mathrm{~mL} / \mathrm{kg}$ of soybean meal. Result showed that the concentration of total sugar and soluble protein of hydrolysed soybean meal increased with the increasing of the extracted ruminal enzyme concentration. The in vivo research aimed to evaluate the use of hydrolyzed soybean meal into the feed formulation for nile tilapia using 5 treatments and 3 replications. The test fish was nile tilapia sized of 2,48 $\pm 0,0183 \mathrm{gram}$ each and was reared under laboratory condition in 15 aquarias size of $50 \mathrm{~cm} \times 60 \mathrm{~cm} \times 50 \mathrm{~cm}$, plotted with 10 fishes each, for 40 days of experiment. Research showed that the use of hydrolyzed soybean meal gave significant increase on feed efficiency compared to the control feed $(P<0.05)$, but not significant increase on growth rate, feed consumption, protein and fat retention. There no significant difference also in the survival rate of the five group of treatments. The extracted ruminal enzyme enable to increase the feed efficiency by way of predigesting the complex protein and carbohydrate contained in the soyben meal.
\end{abstract}

\title{
KEYWORDS: enzymes, sheep rumen liquor, soybean meal, growth, nile tilapia
}

\section{PENDAHULUAN}

Ikan nila merupakan salah satu komoditas pangan utama yang berkembang pesat pada budidaya air tawar di Indonesia. Intensifikasi budidaya ikan nila sangat tergantung pada suplai pakan buatan. Tingginya harga pakan buatan yang disebabkan tingginya harga bahan baku sumber protein, yaitu tepung ikan dan tepung bungkil kedelai impor merupakan salah satu kendala utama dalam pengembangan budidaya ikan nila secara intensif. Penurunan produksi tepung ikan skala global dan meningkatnya permintaan sumber protein tepung ikan serta tepung bungkil kedelai untuk pakan ternak dan ikan mengakibatkan terjadinya peningkatan harga kedua bahan impor tersebut secara signifikan (Gatlin III et al., 2007). Salah satu upaya untuk mengurangi biaya pakan adalah dengan mengurangi ketergantungan pada sumber protein impor dengan cara memanfaatkan bahan baku lokal yang berkualitas, harga layak, persediaannya terjamin, dan tidak bersaing dengan kebutuhan manusia.

Ikan nila adalah ikan omnivora yang cenderung herbivora sehingga lebih mudah beradaptasi dengan jenis pakan yang dicampur dengan sumber bahan nabati seperti tepung bungkil kedelai, tepung jagung, tepung biji kapuk, tepung alfalfa, dan lain-lain (Leobert \& de La Pena, 1987; Borlongan \& Perla, 2003). Permasalahan yang muncul adalah sumber protein nabati termasuk TBK, memiliki nilai kecernaan protein yang lebih rendah dibandingkan tepung ikan (Thorpe \& Beal, 2001), dan adanya kandungan faktor antinutrisi seperti tripsin/protease inhibitor yang dapat mengganggu aktivitas enzim tripsin dan menurunkan performa pertumbuhan serta hipertropi pankreas (Liener, 1994). Permasalahan kedua berkaitan dengan rendahnya kemampuan ikan mencerna bahan nabati yang mengandung karbohidrat tinggi. Rendahnya sekresi enzim amylase dan selulase yang 
berfungsi mencerna karbohidrat pada saluran pencernaan menyebabkan ikan lebih dapat memanfaatkan protein sebagai sumber energi sekaligus pertumbuhan. Hal ini menyebabkan kebutuhan ikan akan sumber protein lebih tinggi daripada hewan darat.

Cairan rumen domba (CRD) merupakan salah satu sumber bahan yang murah dan mudah diperoleh sebagai sumber enzim-enzim hidrolase (Moharery \& Das, 2002). Enzim-enzim hidrolase (enzim yang melakukan reaksi hidrolisis) dalam cairan rumen domba diketahui mampu mencerna berbagai macam substrat zat makanan. Enzim-enzim tersebut antara lain protease/deaminase yang mencerna protein dan menurunkan kadar protease inhibitor dalam bahan nabati, amylase yang mencerna pati, selulase yang mencerna selulosa, hemiselulase (xylanase) yang mencerna hemiselulosa (xylan), lipase yang mencerna lemak, fitase, dan lain-lain (Kung et al., 2000). Adanya enzim-enzim tersebut menyebabkan efektivitas pencernaan dan efisiensi penggunaan pakan pada ternak domba lebih tinggi dibandingkan hewan monogastrik seperti unggas dan ikan, terutama penggunaan bahan pakan berserat kasar tinggi. Selain mengandung enzim, CRD juga mengandung asam-asam amino, vitamin, dan mineral. Produk hasil ekstraksi CRD ini diharapkan dapat secara langsung digunakan sehingga jauh lebih efisien dibandingkan bila harus menggunakan enzim, asam amino, vitamin, dan mineral hasil produksi pabrik. CRD sebagai sumber enzim akan dimanfaatkan untuk menghidrolisis (predigestion) TBKL yang akan digunakan sebagai bahan campuran pakan ikan. Diharapkan enzim amylase dan selulase dalam cairan rumen domba dapat membantu menghidrolisis karbohidrat dan selulosa, dan enzim proteasenya dapat membantu menghidrolisis protein kompleks dan menurunkan tripsin inhibitor dalam TBKL.

Penelitian ini bertujuan mendapatkan informasi manfaat dan peranan ekstrak enzim kasar dari cairan rumen domba (EEK CRD) dalam meningkatkan ketersediaan karbohidrat dan protein dari sumber bahan baku tepung bungkil kedelai lokal (TBKL).

\section{BAHAN DAN METODE}

Percobaan dilaksanakan dalam dua tahap yaitu pertama untuk mengetahui dosis ekstrak EEK CRD yang efektif untuk menghidrolisis TBKL (in vitro) dan kedua untuk mengetahui pengaruh penggunaan TBKL terhidrolisis dalam pakan terhadap pertumbuhan ikan nila (in vivo).

Sebelum dilakukan percobaan I dan II, terlebih dahulu dilakukan proses ekstraksi enzim. Segera setelah domba dipotong, maka isi lambung diambil dengan mengenakan sarung tangan, kemudian diperas dan cairan perasannya ditampung dalam botol sampel. Setiap pekerjaan preparasi ekstraksi dilakukan dalam kondisi suhu dingin (dengan cara menyediakan bongkahan es di dalam cool box).

Ekstraksi enzim kasar mengacu pada metode yang dilakukan Wang et al. (2008), dengan modifikasi pada suhu dan pengenceran media yang digunakan. CRD disentrifus dengan kecepatan $12.000 \mathrm{rpm}$ pada suhu $4^{\circ} \mathrm{C}$ selama 20 menit. Supernatannya, yang dikatagorikan sebagai ekstrak enzim kasar (EEK) disimpan dalam botol sampel di dalam kotak pendingin untuk segera digunakan pada percobaan selanjutnya.

\section{Percobaan I (In vitro)}

Percobaan ini bertujuan untuk mendapatkan konsentrasi EEK CRD yang paling efektif untuk menghidrolisis TBKL sebagai bahan baku pakan untuk ikan nila. Percobaan didesain menggunakan rancangan acak lengkap (RAL) terdiri atas 5 perlakuan dan 3 ulangan. Perlakuan yang diberikan adalah konsentrasi enzim kasar yaitu 0, 200, 400,600, dan $800 \mathrm{~mL}$ EEK CRD/kg TBKL, dengan masa inkubasi 24 jam.

TBKL sebanyak $20 \mathrm{~g}$ disiapkan dalam wadah inkubasi. EEK CRD dicampurkan secara merata pada TBKL dengan dosis sesuai perlakuan yang telah ditentukan, kemudian wadah inkubasi ditutup dengan kertas untuk melindunginya dari binatang pengganggu, dan dibiarkan selama 24 jam (Fitriliyani, 2010).

Parameter yang diamati dalam percobaan ini adalah: 1) kadar protein, lemak, serat kasar, dan BETN TBKL terhidrolisis dengan analisis proksimat, 2) kadar total gula TBKL terhidrolisis (Apriyantono et al., 2000) dan 3) kadar protein terlarut TBKL dengan metode Bradford (1976).

\section{Percobaan II (In vivo)}

Percobaan ini bertujuan untuk mengetahui pengaruh penggunaan TBKL terhidrolisis terhadap pertumbuhan, efisiensi pakan, konsumsi pakan, retensi protein, dan lemak 
serta tingkat sintasan ikan nila, serta mendapatkan persentase TBKL terhidrolisis yang terbaik dalam formulasi pakan.

Perlakuan yang dicobakan adalah formulasi pakan dengan persentase TBKL terhidrolisis yang berbeda (Tabel 1) untuk pakan A, B, C, dan $D$, sedangkan pakan $E$ adalah pakan komersial untuk ikan nila. Sebanyak $800 \mathrm{~mL}$ enzim kasar hasil ekstraksi cairan rumen dicampurkan ke dalam $1 \mathrm{~kg}$ TBKL, diaduk merata dan didiamkan (inkubasi) selama 24 jam. Selanjutnya TBKL terhidrolisis tersebut digunakan sebagai bahan formulasi pada percobaan (Tabel 1), sedangkan hasil analisis proksimat pakan perlakuan disajikan pada Tabel 2.
Ikan nila yang digunakan dalam penelitian in vivo ini berukuran rata-rata $2,48 \pm 0,0183 \mathrm{~g}$ per ekor. Sebanyak 15 buah akuarium berukuran $50 \mathrm{~cm} \times 60 \mathrm{~cm} \times 50 \mathrm{~cm}$ yang dilengkapi sistem resirkulasi, diisi masing-masing sebanyak 10 ekor ikan uji pada setiap akuarium. Pakan uji diberikan tiga kali sebanyak $8 \%$ bobot biomassa per hari.

Sampling dilakukan pada awal, tengah, dan akhir penelitian untuk mengukur bobot biomassa ikan uji di setiap unit percobaan. Pengamatan kualitas air meliputi suhu, oksigen, $\mathrm{pH}$, alkalinitas, amonia dilakukan pada awal, tengah, dan akhir masa penelitian. Penelitian in vivo ini dilakukan selama 40 hari.

Tabel 1. Formulasi pakan buatan untuk ikan nila untuk perlakuan pakan A, B, C, dan D Table 1. Formulation of experimental feed for nile tilapia

\begin{tabular}{|c|c|c|c|c|}
\hline \multirow{2}{*}{$\begin{array}{c}\text { Bahan } \\
\text { Ingredients }\end{array}$} & \multicolumn{4}{|c|}{ Komposisi (Composition) (\%) } \\
\hline & A & B & C & D \\
\hline Tepung ikan (Fish meal) & 10.00 & 10.00 & 10.00 & 10.00 \\
\hline $\begin{array}{l}\text { TBKL terhidrolisis } \\
\text { Hydrolyzed soybean meal }\end{array}$ & 0.00 & 15.00 & 30.00 & 45.00 \\
\hline TBKL (Soybean meal) & 45.00 & 30.00 & 15.00 & 0.00 \\
\hline DDGS (Destiller dried grain with solubles) & 15.60 & 15.60 & 15.60 & 15.60 \\
\hline Tepung pollard (Pollard meal) & 22.43 & 22.43 & 22.43 & 22.43 \\
\hline Tepung sagu (Sagu palm meal) & 2.00 & 2.00 & 2.00 & 2.00 \\
\hline Minyak jagung (Corn oil) & 1.00 & 1.00 & 1.00 & 1.00 \\
\hline Minyak ikan (Fish oil) & 2.00 & 2.00 & 2.00 & 2.00 \\
\hline Premix ${ }^{*}$ & 0.40 & 0.40 & 0.40 & 0.40 \\
\hline Vitamin C & 1.00 & 1.00 & 1.00 & 1.00 \\
\hline Choline chloride & 0.50 & 0.50 & 0.50 & 0.50 \\
\hline Ysine+metionin $(1: 1)$ & 0.07 & 0.07 & 0.07 & 0.07 \\
\hline Jumlah (Total) & 100.00 & 100.00 & 100.00 & 100.00 \\
\hline $\begin{array}{l}\text { Rasio energi : prote in } \\
\text { Energi : protein ratio }\end{array}$ & 8.43 & 8.50 & 8.58 & 8.65 \\
\hline$\%$ Prote in & 32.63 & 33.13 & 33.63 & 34.13 \\
\hline \% Lemak (Lipid) & 10.58 & 10.32 & 10.06 & 9.80 \\
\hline$\%$ BETN / NFE & 30.05 & 29.58 & 29.12 & 28.66 \\
\hline Energi total (Total energy) (kc al $/ \mathrm{kg})$ & $2,750.62$ & $2,735.41$ & $2,720.20$ & $2,704.99$ \\
\hline
\end{tabular}

Kadar vitamin dan mineral per $\mathrm{kg}$ pakan untuk dosis pemberian $5 \mathrm{~kg}$ premix per ton : $20.000 \mathrm{iu}$ vitamin A, 200 iu vit. D3, $200 \mathrm{mg}$ vit. E, $20 \mathrm{mg}$ vit. B1, $30 \mathrm{mg}$ vit. B2, $12 \mathrm{mg}$ vit. B6, $50 \mathrm{mg}$ panthotenic acid, $0,8 \mathrm{mg}$ biotin, $150 \mathrm{mg}$ niacin, $0,05 \mathrm{mg}$ vit. B12, $160 \mathrm{mg}$ vit. C, 4,0 mg cobalt, $40 \mathrm{mg}$ iron, 5,0 mg iodine, $30 \mathrm{mg}$ manganese, $4 \mathrm{mg}$ copper, $4 \mathrm{mg}$ zink, 0,2 mg selenium, $100 \mathrm{mg}$ lisin, $100 \mathrm{mg}$ methionine, $100 \mathrm{mg}$ antioxidant 
Tabel 2. Hasil analisis proksimat pakan percobaan

Table 2. The proximate composition of experimental feed for nile tilapia

\begin{tabular}{lccccccc}
\hline & & \multicolumn{3}{c}{$\%$ Bobot kering (\% Dry weight) } \\
\cline { 3 - 8 } Pakan percobaan $_{\text {Experimental diet s* }}$ & Kadar air & Moist ure & $\begin{array}{c}\text { Protein } \\
\text { Protein }\end{array}$ & $\begin{array}{c}\text { Lemak } \\
\text { Fat }\end{array}$ & $\begin{array}{c}\text { Abu } \\
\text { Ash }\end{array}$ & $\begin{array}{c}\text { Serat } \\
\text { Fibre }\end{array}$ & $\begin{array}{c}\text { BETN } \\
\text { NFE }\end{array}$ \\
\hline A (TBKLT 0\%) & 5.80 & 35.72 & 7.13 & 8.13 & 4.14 & 44.88 \\
B (TBKLT 15\%) & 5.20 & 35.12 & 6.90 & 8.44 & 4.32 & 45.22 \\
C (TBKLT 30\%) & 5.70 & 35.49 & 6.46 & 8.54 & 3.96 & 45.55 \\
D (TBKLT 40\%) & 4.20 & 35.04 & 7.12 & 8.61 & 3.74 & 45.49 \\
E (Pakan komersial) & 9.05 & 35.50 & 7.01 & 7.25 & 4.26 & 45.98 \\
E (Commercialfeed) & & & & & & \\
\hline
\end{tabular}

\% TBKL terhidrolisis (\% of hydrolyzed soybean meal)

\section{HASIL DAN BAHASAN}

\section{Percobaan I (In Vitro)}

Konsentrasi EEK CRD mempengaruhi kadar total gula. Kadar total gula meningkat dengan bertambahnya konsentrasi enzim kasar yang diberikan kepada TBKL. Kadar total gula tertinggi terdapat pada perlakuan $\mathrm{E}(800 \mathrm{~mL} / \mathrm{kg}$ TBKL) dan terendah pada perlakuan A (tidak mendapat EEK CRD) (Gambar 1).

Parameter total gula sangat penting di dalam pengukuran kualitas nutrisi pakan dan bahan baku pakan, karena pada bentuk inilah karbohidrat dapat dicerna dan diserap dengan mudah oleh dinding usus ikan. Endapan yang tidak ikut tersaring pada prosedur pengukuran kadar total gula, adalah bentuk karbohidrat yang tidak mudah dicerna ikan (Piliang \& Djodjosoebagio, 2006).

Hasil pengukuran kadar protein terlarut pada akhir periode inkubasi setelah dihidrolisis dengan enzim kasar pada cairan rumen disajikan pada Gambar 2. Konsentrasi EEK CRD mempengaruhi kadar protein terlarut. Konsentrasi protein terlarut meningkat dengan

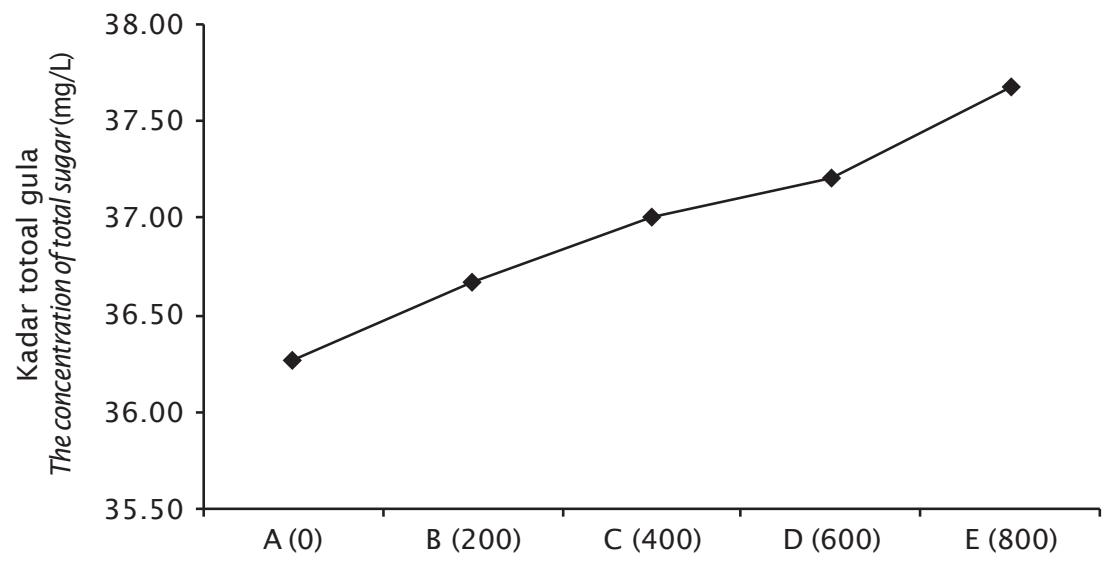

Konsentrasi ekstrak enzim kasar dari cairan rumen domba The concentration of extracted ruminal enzyme $(\mathrm{mL} / \mathrm{kg})$

Gambar 1. Kadar total gula (mg/L) pada TBKL yang dihidrolisis dengan EEK CRD dengan konsentrasi berbeda

Figure 1. Concentration of total sugar of hydrolyzed soybean meal at different dosages of extracted ruminal enzyme 


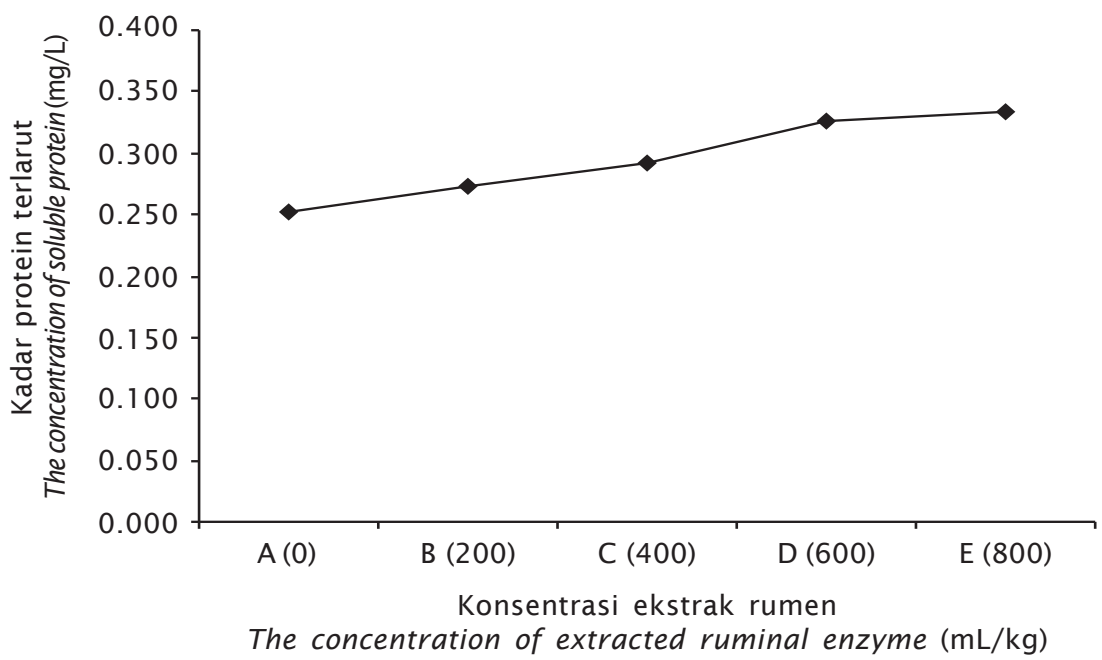

Gambar 2. Kadar protein terlarut (mg/L) pada TBKL yang dihidrolisis dengan EEK CRD dengan konsentrasi berbeda

Figure 2. Concentration of soluble protein of hydrolyzed soybean meal at different dosage of extracted ruminal enzyme

bertambahnya konsentrasi EEK CRD yang diberikan pada TBKL. Kadar protein terlarut tertinggi terdapat pada perlakuan $\mathrm{E}(800 \mathrm{~mL} /$ $\mathrm{kg}$ TBKL), sedangkan yang terendah pada perlakuan $\mathrm{A}(0 \mathrm{~mL} / \mathrm{kg}$ TBKL).

Menurut Tonheim et al. (2007), protein yang larut dalam air (protein terlarut) adalah jenis protein yang yang dapat dicerna dan dimanfaatkan secara efisien oleh benih ikan, dibandingkan dengan protein yang tidak terlarut. Pengukuran parameter jumlah protein terlarut penting dalam suatu kegiatan hidrolisis protein, karena merupakan salah satu tolok ukur keberhasilan aktivitas hidrolisis protein.

TBKL akan mengalami perombakan protein yang signifikan bila dihidrolisis oleh enzim protease yang terdapat di dalam EEK CRD. Beal et al. (1998) menggunakan teknik in vitro untuk mengevaluasi kemampuan beberapa jenis enzim protease dalam meningkatkan kecernaan nitrogen TBK, dan menemukan peningkatan sebesar $12 \%$ daripada kontrolnya. Rooke et al. (1998) melaporkan adanya peningkatan konsentrasi asam amino TBK setelah di-treatment dengan enzim protease. Hou et al. (2010) yang menggunakan kompleks enzim protease untuk menghidrolisis limbah ikan Pollock Alaska yang terdiri atas daging dan tulang buangan melaporkan adanya penurunan signifikan jumlah ikatan peptida.
Hasil proksimat terhadap TBKL yang telah dihidrolisis dengan EEK CRD disajikan pada Tabel 3. Kadar protein kasar, lemak, dan BETN tidak dipengaruhi oleh dosis EEK CRD yang diberikan pada TBKL.

\section{NFE: Nitrogen Free Extract}

Protein kasar, lemak, dan BETN pada kelima perlakuan tidak berbeda nyata, karena baik produk hasil hidrolisis yang tercerna maupun yang tidak, akan tetap terbaca secara total pada pengukuran protein kasar, lemak, dan BETN. Apabila produk-produk hidrolisis tidak kita pisahkan, maka analisis proksimat tidak akan bisa membedakan di antara produk yang kecernaannya tinggi dengan yang rendah, karena yang terbaca adalah protein kasar, lemak, dan BETN total. Secara logis BETN akan meningkat apabila ada enzim selulase yang aktif memecah selulosa menjadi bentuk karbohidrat sederhana, sehingga selulosa yang semula terbaca sebagai serat kasar, akan berubah bentuk menjadi glukosa yang akan terbaca sebagai BETN pada analisis proksimat. Namun hasil penelitian ini tidak mendapatkan indikasi adanya peningkatan kadar BETN pada TBKL terhidrolisis. Diduga enzim selulase tidak cukup aktif bekerja pada saat inkubasi, karena masing-masing enzim memiliki prasyarat suhu dan $\mathrm{pH}$ optimal yang berbeda-beda. 
Tabel 3. Hasil analisis proksimat TBKL yang dihidrolisis dengan EEK CRD

Table 3. Proximate composition of hydrolyzed soybean meal

\begin{tabular}{cccccc}
\hline $\begin{array}{c}\text { TBKL terhidrolisis } \\
\text { Hydrolyzed soybean } \\
(\mathbf{m L} / \mathbf{k g})\end{array}$ & $\begin{array}{c}\text { Protein kasar } \\
\text { Crude prot ein } \\
\mathbf{( \% )}\end{array}$ & $\begin{array}{c}\text { Lemak } \\
\text { Fat } \\
\text { (\%) }\end{array}$ & $\begin{array}{c}\text { Serat kasar } \\
\text { Crude fibre } \\
\text { (\%) }\end{array}$ & $\begin{array}{c}\text { Abu } \\
\text { Ash } \\
\text { (\%) }\end{array}$ & $\begin{array}{c}\text { BETN } \\
\text { NFE } \\
\text { (\%) }\end{array}$ \\
\hline A (0) & $46.12 \pm 0.03$ & $2.09 \pm 0.06$ & $9.20 \pm 0.33$ & $3.56 \pm 0.34$ & $60.97 \pm 0.13$ \\
B (200) & $46.42 \pm 0.24$ & $2.59 \pm 0.16$ & $10.21 \pm 0.14$ & $3.74 \pm 0.30$ & $62.95 \pm 0.26$ \\
C (400) & $46.38 \pm 0.47$ & $2.35 \pm 0.30$ & $9.15 \pm 0.17$ & $3.90 \pm 0.14$ & $61.79 \pm 0.51$ \\
D (600) & $46.37 \pm 0.64$ & $2.59 \pm 0.41$ & $9.66 \pm 0.06$ & $3.76 \pm 0.09$ & $62.38 \pm 0.60$ \\
E (800) & $46.06 \pm 0.31$ & $3.04 \pm 0.21$ & $10.21 \pm 0.62$ & $3.54 \pm 0.23$ & $62.85 \pm 0.82$ \\
\hline
\end{tabular}

BETN: Bahan ekstrak tanpa nitrogen (Nitrogen free extract)

Dari hasil penelitian in vitro ini disimpulkan bahwa konsentrasi $800 \mathrm{~mL} / \mathrm{kg}$ TBKL memberikan hasil paling baik, dengan kadar total gula dan protein terlarut tertinggi. Konsentrasi $800 \mathrm{~mL} / \mathrm{kg}$ TBKL selanjutnya digunakan untuk menghidrolisis TBKL yang akan digunakan dalam formulasi pakan nila dalam percobaan in vivo.

\section{Percobaan II (In Vivo)}

Hasil pengukuran rata-rata pertambahan bobot ikan setelah 40 hari pengamatan diperlihatkan pada Tabel 4. Secara statistika, tidak ada perbedaan nyata di antara kelima perlakuan untuk parameter laju pertumbuhan spesifik, jumlah konsumsi pakan, retensi protein, dan retensi lemak, namun ada perbedaan nyata untuk parameter efisiensi pakan (Tabel 4). Efisiensi pakan tertinggi terdapat pada pakan $D$ yang menggunakan TBKL terhidrolisis sebesar $45 \%$ dalam formulasi, yang mencapai $44,43 \% \pm 0,24 \%$ dan terendah pada perlakuan pakan formulasi kontrol (A).

Berdasarkan parameter efisiensi pakan, pakan formulasi kontrol (A) dan pakan komersial E berada di posisi terendah $(41,29 \%$ dan $41,44 \%)$, sedangkan pakan $\mathrm{D}$ di posisi tertinggi $(44,43 \%)$. Secara umum pakan yang

Tabel 4. Laju pertumbuhan spesifik (LPS), jumlah konsumsi pakan (JKP), efisiensi pakan (EP), retensi protein (RP), retensi lemak (RL), dan sintasan (SR) ikan nila

Table 4. The average of specific growth rate, feed consumption, feed efficiency, protein and fat retention, and the survival rate of nile tilapia

\begin{tabular}{lccccc}
\hline & \multicolumn{5}{c}{ Pakan perlakuan (Experimental diets) } \\
\cline { 2 - 6 } & $\begin{array}{c}\text { Kont rol } \\
\text { Control feed }\end{array}$ & $\begin{array}{c}\text { TBKLT }^{*} \\
\mathbf{1 5 \%}\end{array}$ & $\begin{array}{c}\text { TBKLT } \\
30 \%\end{array}$ & $\begin{array}{c}\text { TBKLT } \\
\mathbf{4 5 \%}\end{array}$ & $\begin{array}{c}\text { Pakan komersial } \\
\text { Commercial feed }\end{array}$ \\
\cline { 2 - 6 } & A & B & C & D & E \\
\hline LPS (\%) & $2.60 \pm 0.21^{\mathrm{a}}$ & $2.76 \pm 0.13^{\mathrm{a}}$ & $2.80 \pm 0.09^{\mathrm{a}}$ & $2.77 \pm 0.06^{\mathrm{a}}$ & $2.61 \pm 0.14^{\mathrm{a}}$ \\
JKP (g) & $88.77 \pm 7.93^{\mathrm{a}}$ & $95.15 \pm 0.62^{\mathrm{a}}$ & $94.00 \pm 5.29^{\mathrm{a}}$ & $91.67 \pm 2.89^{\mathrm{a}}$ & $89.69 \pm 8.27^{\mathrm{a}}$ \\
EP (\%) & $41.29 \pm 1.20^{\mathrm{b}}$ & $42.71 \pm 2.98^{\mathrm{ab}}$ & $43.92 \pm 0.46^{\mathrm{a}}$ & $44.43 \pm 0.24^{\mathrm{a}}$ & $41.44 \pm 0.12^{\mathrm{b}}$ \\
RP (\%) & $26.63 \pm 0.31^{\mathrm{a}}$ & $28.54 \pm 1.53^{\mathrm{a}}$ & $28.20 \pm 0.59^{\mathrm{a}}$ & $27.50 \pm 0.34^{\mathrm{a}}$ & $26.91 \pm 0.59^{\mathrm{a}}$ \\
RL (\%) & $61.53 \pm 1.42^{\mathrm{a}}$ & $63.35 \pm 4.20^{\mathrm{a}}$ & $65.08 \pm 0.80^{\mathrm{a}}$ & $65.88 \pm 0.43^{\mathrm{a}}$ & $61.73 \pm 0.42^{\mathrm{a}}$ \\
SR (\%) & $100^{\mathrm{a}}$ & $100^{\mathrm{a}}$ & $100^{\mathrm{a}}$ & $100^{\mathrm{a}}$ & $100^{\mathrm{a}}$ \\
\hline
\end{tabular}

Keterangan (Note):

Angka yang diikuti huruf superscript yang sama menunjukkan perbedaan yang tidak nyata $(P>0,05)$ antar perlakuan (The values under the same superscript indicate no significant difference $(P>0.05)$ )

" TBKLT: Tepung bungkil kedelai lokal terhidrolisis (Hydrolyzed soybean meal) 
mengandung TBKL terhidrolisis ( $B, C$, dan $D$ ) lebih tinggi daripada pakan kontrol A. Selisih yang signifikan secara statistika terdapat di antara perlakuan D dengan A dan E. Ini mengindikasikan bahwa dalam hal performa efisiensi pakan, pakan A dan E sama, dan perlakuan hidrolisis TBKL dengan enzim rumen (pakan D) mampu meningkatkan efisiensi pakan secara signifikan. Efisiensi pakan merupakan pencampuran andil dari parameter laju tumbuh yang menghasilkan nilai deposisi bobot dengan parameter konsumsi pakan. Laju tumbuh yang tinggi disertai dengan konsumsi pakan efisien, akan menghasilkan nilai efisiensi pakan yang paling tinggi.

Meningkatnya nilai efisiensi pakan pada perlakuan $\mathrm{D}$, diduga disebabkan oleh lebih tingginya kadar protein terlarut di dalamnya, sebagai kontribusi dari TBKL terhidrolisis (45\%) yang terkandung di dalam formulasinya. Peningkatan jumlah protein terlarut setelah dihidrolisis, merupakan cerminan peningkatan daya cerna, karena protein terlarut, adalah jenis protein yang lebih mudah dicerna. Ghazi et al. (2002; 2003) dan Marsman et al. (1997) melaporkan adanya peningkatan kecernaan protein pakan yang berbasis TBK setelah ditreatment dengan enzim protease, untuk ayam broiler.

Untuk parameter laju pertumbuhan, meskipun tidak ada perbedaan nyata di antara kelima perlakuan, namun ada kecenderungan bahwa pakan $C$ dan $D$ lebih tinggi daripada pakan A, yang berarti bahwa pakan yang mengandung TBKL terhidrolisis memiliki nilai SGR yang lebih tinggi daripada pakan kontrol. Rosmawati (2005) memberikan hasil serupa, yaitu penambahan enzim pepsin dan pankreatin pada pakan komersial tidak berpengaruh nyata terhadap laju pertumbuhan benih gurame, meskipun ada peningkatan signifikan untuk kecernaan protein pakannya. Bertambahnya jumlah protein terlarut pada pakan yang mendapat TBKL terhidrolisis, ternyata tidak secara otomatis menaikkan laju pertumbuhan ikan nila. Peningkatan Iaju pertumbuhan, mungkin akan lebih dipengaruhi oleh adanya penambahan jumlah asam amino esensial tertentu yang menjadi pembatas dalam formulasi suatu pakan, dan bukan asam amino lain yang jumlahnya mungkin sudah cukup.

Penambahan jumlah total gula (gula sederhana) sebagai produk hidrolisis TBKL juga tidak menyebabkan adanya peningkatan signifikan untuk parameter pertumbuhan. Laju pertumbuhan ikan yang mengkonsumsi pakan A tidak berbeda nyata dengan pakan $D$. Demikian juga antara perlakuan pakan B (15\% TBKL terhidrolisis) dan D (45\% TBKL terhidrolisis).

Karbohidrat bentuk monosakarida (seperti glukosa atau gula sederhana lainnya) ternyata justru kurang bisa dimanfaatkan oleh ikan nila, dibandingkan dengan dextrin dan pati. Dilaporkan bahwa ikan tilapia justru memanfaatkan pati (polisakarida) lebih baik dibandingkan glukosa (monosakarida) (Anderson et al., 1984; Tung \& Shiau, 1991; Shiau \& Chen, 1993; Shiau \& Lin, 1993). Disebutkan juga bahwa tilapia memanfaatkan disakarida lebih baik dibandingkan glukosa, tetapi pati masih lebih baik dibandingkan disakarida. Untuk kelompok disakarida, maltosa paling baik dimanfaatkan oleh tilapia, diikuti oleh sukrosa dan laktosa (Shiau \& Chuang, 1995).

Permasalahan utama kemampuan fisiologis dan biokimiawi badan ikan berkaitan dengan karbohidrat, adalah bukan pada kemampuan mencerna (level digestibility), tetapi justru di level metabolisme. Meskipun pakan yang diberikan mengandung karbohidrat yang mudah dicerna dan diserap oleh mukosa usus ikan, tetapi kemampuannya memanfaatkan karbohidrat dalam proses metabolisme sangat rendah. Rendahnya sekresi insulin dalam darah menyebabkan kadar glukosa darah dalam tubuh ikan lambat dimanfaatkan, dan lambat untuk diturunkan.

Meskipun pada pakan C dan D kadar protein terlarut lebih tinggi dibandingkan pakan A, namun apabila sumber karbohidratnya kurang dapat dimanfaatkan dalam proses metabolisme, maka sumber protein akan diambil dan dimanfaatkan sebagai penghasil energi, sehingga pemanfaatan protein sebagai materi pembangun akan berkurang, dan fungsi protein sparing effect yang sangat diharapkan tidak dapat bekerja.

Jumlah pakan yang dikonsumsi ikan nila dari kelima perlakuan juga mengalami perbedaan. Meskipun selisihnya belum signifikan secara statistika, konsumsi pakan B, C, dan D $(95,15 ; 94,00$; dan $91,67 \mathrm{~g})$ meningkat dibandingkan konsumsi pakan A $(88,77 \mathrm{~g})$. Data visual di lapangan menunjukkan bahwa ikan nila lebih cepat menghabiskan pakan B, C, dan $D$ dibandingkan dua jenis pakan lainnya. Hal ini menunjukkan bahwa inkubasi TBKL 
Tabel 5. Kualitas air media selama penelitian

Table 5. The quality of rearing water during the experiment

\begin{tabular}{lccccc}
\hline \multirow{2}{*}{$\begin{array}{c}\text { Parameter } \\
\text { Paramet er }\end{array}$} & \multicolumn{5}{c}{ Perlakuan (Treatments) } \\
\cline { 2 - 6 } & A & B & C & D & E \\
\hline Suhu $\left({ }^{\circ} \mathrm{C}\right)$ & $28-30$ & $28-30$ & $28-30$ & $28-30$ & $28-30$ \\
DO (mg/L) & $7.6-9.7$ & $6.2-8.4$ & $8.0-9.5$ & $6.8-8.4$ & $6.2-8.4$ \\
$\mathrm{pH}$ & $7.0-7.5$ & $7.0-7.5$ & $7.0-7.5$ & $7.0-7.5$ & $7.0-7.5$ \\
Alkalinitas (mg/L) & $86-100.2$ & $81-103$ & $87-108$ & $83-101$ & $86-100$ \\
Amoniak (mg/L) & $0.019-0.023$ & $0.022-0.027$ & $0.017-0.019$ & $0.024-0.029$ & $0.017-0.019$ \\
\hline
\end{tabular}

dengan enzim rumen ternyata dapat meningkatkan palatabilitasnya, melalui perbaikan aromanya.

Tidak ada perbedaan nyata untuk parameter sintasan, yang mengindikasikan bahwa ekstrak enzim rumen tidak mempengaruhi parameter ini. Kelima perlakuan memiliki nilai SR yang sama yaitu $100 \%$. Tingkat sintasan yang tinggi juga didukung oleh terjaganya kualitas air media hidup ikan nila (Tabel 5). Sistem resirkulasi, penyiponan feses, dan pembersihan bak filter resirkulasi yang rutin dilakukan dan pencahayaan dengan lampu TL telah mampu menjaga kualitas air media tetap stabil dan sesuai untuk mendukung kehidupan ikan nila yang optimal.

\section{KESIMPULAN}

Hidrolisis TBKL dengan ekstrak enzim kasar dari cairan rumen domba (EEK CRD) dapat meningkatkan kadar total gula dan kadar protein terlarut. Perlakuan hidrolisis TBKL dapat meningkatkan efisiensi pakan secara signifikan, namun tidak untuk parameter laju pertumbuhan, konsumsi pakan, retensi protein, dan retensi lemak. Persentase TBKL terhidrolisis sebanyak $45 \%$ dalam formulasi pakan menghasilkan performa efsiensi pakan yang paling tinggi.

\section{DAFTAR ACUAN}

Anderson, J., Jackson, A.J., Matty, A.J., \& Capper, B.S. 1984. Effect of dietary carbohydrate and fibre on the tilapia Oreochromis niloticus (Linn). Aquaculture, 37: 303-314.

Apriyantono, A., Fardiaz, D., Puspitasari, N.L., Sedarnawati, \& Budiyanto, S. 2000. Analisis Pangan, Petunjuk Laboratorium. IPB Press. Bogor, hlm. 42-47.
Beal, J.D., Brooks, P.H., \& Schulze, H. 1998. The effect of pretreatment with different proteases on the in vitro digestibility of nitrogen in raw soya bean and four different full fat soya bean meals. In: van Arendonk J.A.M., editor. Book of Abstracts of the $49^{\text {th }}$ Annual Meeting of the European Association for Animal Production, Warsawa, Polandia. Wageningen Pers, Wageningen, The Netherlands, $264 \mathrm{pp}$.

Borlongan, I.G. \& Perla, E.S. 2003. Potential of feed pea (Pisum sativum) meal as a protein source in practical diets for milkfish (Chanos chanos Forskal). Aquaculture, 225 (1-4): 89-98.

Bradford, M.M. 1976. A rapid and sensitive methods for the quantization of microgram quantities of protein utilizing the principle of protein-dye binding. Anal. Biochem., 72: 248-254.

Fitriliyani, I. 2010. Peningkatan Kualitas Nutrisi Tepung Daun Lamtoro dengan Penambahan Ekstrak Enzim Cairan Rumen Domba (Ovis aries) untuk Bahan Pakan Ikan Nila (Oreochromis niloticus). Disertasi. Mayor Ilmu Akuakultur Pascasarjana, IPB, p. 33-39.

Gatlin III, D.M., Barrows, F.T., Brown, V., Dabrowski, V., Gaylord, T.G., Hardy, R.W., Herman, E., Hu, G., Krogdahl, A., Nelson, R., Overturf, K., Rust, M., Sealey, W., Skonberg, D., Souza, E.J., Stone, D., Wilson, R., \& Wurtele, E. 2007. Expanding the utilization of sustainable plant products in aquafeeds: a review. Aquaculture Research, 38: 551579.

Ghazi, S., Rooke, J.A., Galbraith, H., \& Bedford, M.D. 2002. The potential for the improvement of the nutritive value of soya bean meal by different proteases in broiler chicks 
and broiler cockerels. Br. Poult. Sci., 43: 7077.

Ghazi, S., Rooke, J.A., \& Galbraith, H. 2003. Improvement of the nutritive value of soybean meal by protease and alphagalactosidase treatment in broiler chockerels and broiler chicks. Br. Poult. Sci., 44: 410-418.

Hou, H., Li, B., Zhao, X., Zhang, Z., \& Li, P. 2010. Optimization of enzymatic hydrolysis of Alaska Pollock frame for preparing protein hydrolysates with low bitterness. LWT-Food Science and Technology, 44(2): 421-428.

Kung, L.J.R., Treacher, R.J., Nauman, G.A., Smagala, A.M., Endres, K.M., \& Cohen, M.A. 2000. The effect of treating forages with fibrolytic enzymes on its nutritive value and lactation performance of dairy cows. J. Dairy Sci., 83: 115-122.

Leobert \& de La Pena. 1987. Evaluation of various leguminous seed as protein sources for milkfish Chanos-chanos Forskal juveniles. Asian Fisheries Science 1, 198: 1828.

Liener, I.E. 1994. Implications of antinutritional components in soybean foods. Critical reviews in Food Science and Nutrition, 34(1): 31-67.

Marsman, G.J.P., Gruppen, H., van der Pool, A.F.B., Kwakkel, R.P., Verstegen, M.W.A., \& Voragen, A.G.J. 1997. The effect of thermal processing and enzyme treatments of soybean meal on growth performance, ileal nutrient digestibilities and chime characteristics in broiler chicks. Poult. Sci., 76: 864-872.

Moharery, A. \& Das, T.K. 2002. Correlation between microbial enzyme activities in the rumen fluid of sheep under different treatments. Reprod. Nutr. Dev., 41: 513-529.

Piliang, W.G. \& Djodjosoebagio Al Haj, S. 2006. Fisiologi Nutrisi. IPB Press, 1: 181-190.

Rooke, J.A., Slessor, M., Fraser, H., \& Thomson, J.R. 1998. Growth performance and gut function of piglets weaned at four weeks of age and fed protease-treated soyabean meal. Animal Feed Science and Technology, 70: 175-190.

Rosmawati. 2005. Hidrolisis pakan buatan oleh enzim pepsin dan pankreatin untuk meningkatkan daya cerna dan pertumbuhan benih ikan gurami (Osphronemous gouramy Lac). Tesis. Program Pascasarjana, Institut Pertanian Bogor, hlm. 23-33.

Shiau, S.Y. \& Chen, M.J. 1993. Carbohydrate utilization by tilapia (O. niloticus $x O$. aureus) as influenced by different chromium sources. Journal of Nutrition, 123: 1,7471,753 .

Shiau, S.Y. \& Lin, S.F. 1993. Effect of supplemental dietary chromium and vanadium on the utilization of different carbohydrates in tilapia (O. niloticus $\times O$. aureus). Aquaculture, 110: 321-330.

Shiau, S.Y. \& Chuang, J.C. 1995. Utilization of dissacharides by juvenile tilapia ( $O$. niloticus x 0 . aureus). Aquaculture, 133: 249-256.

Thorpe, J. \& Beal, J.D. 2001. Vegetable Protein Meals and the Effects of Enzymes in: Enzymes in Farm Animal Nutrition. Bedford MR, Partridge GG (Eds.). CAB International, p. 125-143.

Tonheim, S.K., Nordgreen, A., Hogoy, I., Hamre, K., \& Ronnestad, I. 2007. In vitro digestibility and water soluble protein fractions of some common fish larval feeds and feed ingredients. Aquaculture, 262: 426-435.

Tung, P.H. \& Shiau, S.Y. 1991. Effect of meal frequency on growth performance of hybrid tilapia, Orechromis niloticus $\times O$. aureus fed different carbohydrate diets. Aquaculture, 92: 343-350.

Wang, S.L., Yang, C.H., Liang, T.W., \& Yen, Y.H. 2008. Optimization of condition for protease production by Chryseobacterium taenense TK U001. Bioresource Technology, 99: 3,700-3,707. 